УАК 130.3

DOI: $10.26565 / 2226-0994-2020-63-23$

\title{
Юнія Бродецька
}

\section{МЕТАФІЗИЧНА ПРИРОАА ЗНАНЬ: СВІТАО, ЩО ПРОСВІТАЮЕ}

Стаття присвячена розгляду феномена знання як метафізичної основи буттевого порядку. Семантичне наповнення цього слова зберігає в собі значення «світла істини», «розуму», «слова», що АОзволяе АюАині бачити навколишній світ, тобто робить його «проявленим», «ясним», «зрозумілим». Йдеться про знання, які спрямовані до самої есенції Аюдської Ауші. Це, по суті, ціннісне знання, що «зцілює», тобто єАнає всі аспекти АюАської природи (Ауховні, фізичні), а тому потребує особливого інтуїтивного сприйняття, змушує віАчувати, загАиблюватися в те, що ми пізнаємо. Як «ефір», тобто інформаційне середовище, яке зАатне сповнювати й надихати АюАину, перетворювати, єАнати, віАтворювати ії зв'язок з реальністю, Ауховні знання ведуть до віАповіАності особистості онтологічним законам спільного буття. Інакше кажучи, це принципи, які закладені в основу буттєвої цілісності Аюдини, іiі розвитку та формування Аюдського спів-буття. У цій перспективі йдеться, власне, про те, що в основі буття АюАини Аежить потреба в Ауховних знаннях. Саме останні є тим «трансцендентним світлом», яке наділене перетворювальною потенцією. Це знання, що вілповіАає характеру есенціальності мюАини, потребам ії Ауші. Отже, потреба у віАкритті цього знання Аля себе - тобто пізнання - і є тією силою, що рухає особистість в ії життєвих виборах, вибудовує сенс і перспективу ії життя. Розуміючи Аюдину та навколишній світ як цілісну спів-буттєвість, авторка статті Аосліджує взаємозв'язок між внутрішнім станом особистості (iі екзистенційною установкою) i навколишнім світом як живим, Аинамічним середовищем. Світло, що є онтологічною умовою порялку, життя, є у своєму метафізичному статусі основою самого буття, а отже, воно є тим, що сповнює нас життєвою силою, а також тим, що є несумісним з будь-яким проявом темряви, невігластва, зла. Саме тому зАатність бачити

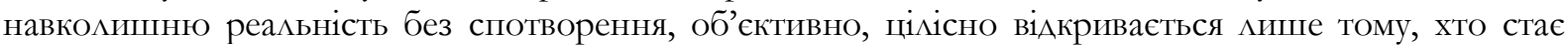
носієм цього світла.

Ключові слова: знання, пізнання, метафізика, світло, спів-буття.

Проблематика знання, його природи, значення Аля Аюдини, апріорності, гносеологічного потенціалу тощо створюе основу Аля філософського Аискурсу протягом всієі історії формування останнього. Починаючи із Сократа, Платона, Арістотеля, і звертаючись до І. Канта, І.В. Аяйбніца, Аж. Аока та навіть представників сучасної аналітичної традиції, можна побачити, що питання сутності та потенціалу знання неодмінно перебуває у фокусі філософських досліАжень. Проте, Аивлячись на спроби сучасної науки «операціоналізувати» цей феномен, а також зважаючи на невпинне прагнення захіАної цивілізації «володіти» знанням, можна стверджувати, що з’ясування метафізичного призначення знання стає все більш актуальним дослідницьким завданням.

Метою запропонованої статті є концептуалізація онтологічних та екзистенційних засад феномену духовного знання, яка спирається на семантичний аналіз відповідного поняття.

Отже, тільки завдяки світлу й зАатності сприймати його мюдина може бачити навколишній світ (хоча, з погляду фізики, ми бачимо не самі речі, а ї світлове віАображення). ЗгіАно з давніми біблейськими текстами світло (iвp. מאור) є першим творінням Божим. Так, тлумачники Аавньоєврейської мови звертають увагу на те, що Книга Буття починається зі слова бе-решит, яке стоїть у сполученій формі, тому точний переклаА фрази «На початку створив Бог небо і землю» має такий вигляд: «На початку творення Всевишнім неба и землі <..> сказав Всевишній: "Нехай буде світло" - i з'явилося світло» (тут і далі переклаА мій. - Ю. Б.) [Штейнзальц, 1998]. «I побачив Бог

(C) Бродецька Ю. Ю., 2020.

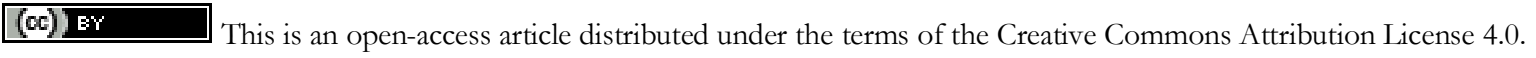


світло, що Аобре воно, і Бог віААілив світло віА темряви. I Бог назвав світло: Аень, а темряву назвав: Ніч» (Бут. 1: 3-5). Часто піАкреслюється, що світло наділене особливим статусом, незалежним віА небесних світил, створених тільки на четвертий Аень творіння [Аив.: Еврейская энциклопедия Брокгауза и Ефрона, 1906-1913]. Тобто світло тут є центральним елементом світобудови. Ба навіть більше, воно є умовою порядку Всесвіту, самого життя.

Цікаво, що в сучасних словниках лексема «світло» зафіксована зі значенням «електромагнітне випромінювання, що сприймається оком і робить видимим навколишній світ» [Словарь русского языка, 1983]. Тобто семантика слова *svèt- визначас, що світло - че променева енергія, яка продукується, іде від джерела та проявляе навколишній світ, тобто робить його видимим, у значенні «ясним», «зрозумілим». ЙАеться про джерело, яким у Аавньоєврейській мові позначали саме Божественне світло (івр. רік - ор), що розкриває

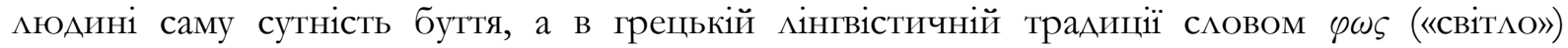
позначали саме євангельське вчення, що просвітлює розум Аюдини. Тобто сама стихія світла розумілася божественною: такою, Ао якої не можна віАнести нічого темного, злого, гріховного $^{1}$ [Полный церковнославянский словарь Аьяченко, 1899]. Як зазначає у своїй роботі «Світло в темряві» С. Франк, у цьому разі йлеться про «світло істинне» (Аавньогр. $\varphi \tilde{\omega} \sigma \dot{\alpha} \lambda \eta \theta \imath \iota \dot{v})$, тобто світло, що сходить віА Бога, - те світло божественного Аогосу, через яке сам світ «почав бути». Тому не може бути й мови про те, щоб це світло мише слабко мерехтіло і через це не було зАатним розігнати пітьму й осяяти світ. Воно не тільки є невгасимим, але за своєю іманентною метафізичною суттю є безмірно могутнім, тобто всемогутне - бо божественне - світАо призначене у світі світити в темряві [Франк, 1998, с. 18].

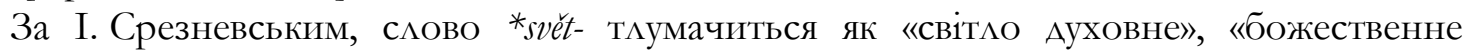
начало» [Срезневский, 1989, с. 295-297]. Таке значення слова в його семантичній структурі важливе саме у зв'язку з тим, що в сакральних текстах воно позначало властивість, стан Бога (порівняйте, наприклаА, в Остромировому Євангелії віА 1057 року: «Бэ свэть истиньныи, иже просвэщаеть всякого человека» [Срезневский, 1989, с. 135]). ВіАповіАно, прикметник «світАий», окрім значень «ясний i могічний», «піАнесений», «благородний», тлумачиться як «той, що відноситься до Великодня, Пасхальний» [САоварь русского языка, 1983]. Інакше кажучи, *svét- є рівним світлом, світлом віл Ажерела, що АОзволяє бачити навколишній світ. Невипадково, що Аля характеристики цього слова важлива його спрямованість (Аієслово «світити» функціонує в контекстах: світити - куАи?).

Продовженням полісемантики слова «світло» виступає лексема «світ» у значенні «земля зі всім існуючим на ній». Таке тлумачення зафіксовано, наприклаА, у текстах XI ст., Ае «свэть» це і «протилежність темряві, світло» [Словарь русского языка XI-XVII вв., 1996, с. 136], і «земне життя». Водночас значення «земля, світ, всесвіт, всі країни» та «світ, всесвіт, життя, АюАське суспільство» у слова «свэть» зустрічається тільки з XV ст. [Словарь русского языка XI-XVII вв., 1996, с. 136]. У В. Аа^я зустрічаємо такі визначення іменника «свэтъ»: 1) «стан, протилежний темряві»; 2) «ріА АюАський, світ, АюАське суспільство» [Ааль, 1880-1882]. У Аавньогрецькому

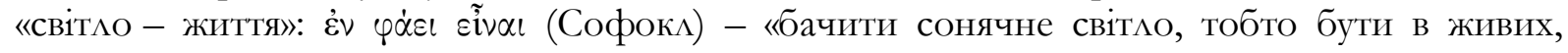
жити»; $\dot{\varepsilon} \varsigma \varphi$ 'Е $\lambda \theta \varepsilon \iota$ (Піндар) - «з'явитися на світ, народитися» [Аревнегреческо-русский

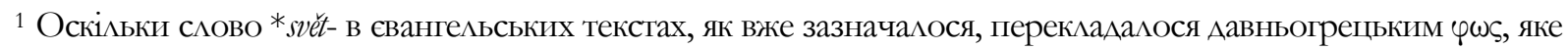

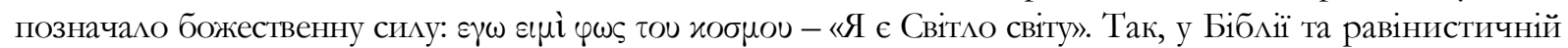
літературі, як зазначається в біблейській енциклопедії Брокгауза, слово «світло» зустрічається у таких значеннях: 1) світло, що було сотворене Богом за Його волею (Бут. 1:3-5) у перший Аень творення світу, ще Ао того, як були створені джерела світла - «світила на тверАі небесній»; 2) слово «світло» зустрічається і в метафоричному застосуванні, наприклаА: «говоріть при світАі» (тобто при свіАках, пуб์ (ічно); 3) у сенсі етичного критерію АюАських вчинків - всього, що е протилежним гріху [Биболейская энциклопедия Брокгауза, 1999].
} 
словарь, 1958]. У матинській мові lих - це і «світло», i «життя»: luce privāre (Цицерон) «позбавити життя, віднімати життя» [Аворецкий, 2000].

Слова 3 таким значенням зустрічаються у всіх слов'янських мовах. Порівняйте, наприклад: українське «світло» - «світло, світ, всесвіт», болгарське «світло» - «світ, світанок», чеське «svět» - «світ», словацьке «svet» - «світ» [Miklošich, 1886]. Як зазначають сучасні АосліАники мови, міцні зв'язки значень «світло» $\mathrm{i}$ «бачення» в історії цього етимологічного гнізда виявляються Аосить чітко, що експліковано в основному значенні слова: «випромінювати, тобто робити видимим навколишній світ» ${ }^{2}$ [Хайдеггер, 1997]. ААя порівняння, у болгарському словнику XIX ст. слова «свэтило» і «виАэло» - «світильник» взаємозамінними, а в білоруській мові Аієслово «свяціць» має семантику «світити, бачити» [Белорусско-русский словарь, 1962, с. 845]. В історії інших «світлолексем» зустрічаємо схожі варіанти. НаприклаА, чеське «blýskati» (se) - «киАати погляА, поглянути»; у словенській мові функціонує Аієслово «blãskăc» - «Аивитися, киАати погляА»; у болгарській «блѐща» - «розкривати широко очі, витріщатися» [Этимологический словарь славянских языков, 1975, с. 64].

Ба навіть більше, сусіАство значень «світити» i «бачити» $є$ Аоволі частим в індоєвропейських мовах. Так, у Аавньоіндійській мові є слова $з$ такими значеннями: bhätih - «світло», бха̄nam - «світити, 3’являтися, бачити» [Miklošich, 1886]; у Аавньогрецькій мові генетично споріАнені $\lambda \varepsilon \dot{\sigma \sigma \sigma \omega}$ - «Аивитися» і $\lambda \varepsilon \cup x \dot{\varsigma}$ - «світАий» [Аворецкий, 1958]. Водночас поява значення «бачити» обумовлена здатністю світла робити світ виАимим.

У Аавніх сакральних текстах «світцо» також взаємопов'язане з поняттям «слово». Світло - найвищий Божий Аар, що сповнюе Аюдське життя суттю, сенсом - Ауховністю. Це є Божественною ознакою, яка притаманна і мюдині, але вимагає свого розкриття. Бог є Світлом, оскільки Він володіє найвищою істиною та всебаченням: «Він відкриває глибоке і сокровенне, знає, що є у мороці і світ перебуває з Ним» (Аан. 2:22). Світло - це знання Боже, що просвітлюе мюдину. Таке сакральне світло в іудео-християнській традиції символізує Божественну природу, яка творить, оживляє, виправляє, сповнює собою ефір Всесвіту, це «світло віри і розуму», тобто життєвої сили, і всього, «що робить ясним, зрозумілим світ», «радісним і щасливим життя»: «Тако Аа сияетъ свэтъ ваш предъ чл(о)вкы, Аа узьрять дела ваша добрая» (Матф. V, 16), Мст. Єв., 236, XI-XII ст. [Словарь русского языка XI-XVII вв., 1996, с. 136].

Сучасна семантика слова * svét- загалом зберігає значення «світла істини», «розуму» ${ }^{3}$. ЙАеться про знання, що спрямовані до самої есенції мюдської Ауші. Це, по суті, иіннісне знання, що здатне «зиілювати душі», а тому потребуе особливого інтуїтивного сприйняттяя, змушує відиувати, заглиблюватися у те, що ми пізнасмо. Як «знання-ефір», тобто інформаційне середовище, яке здатне сповнювати й надихати нас, перетворювати, єАнати, віАтворювати зв'язок Аюдини з реальністю, такі знання ведуть Ао віАповіАності особистості онтологічним законам самого буття. Це принщипи, що закладені в основу буттєвої иілісності - розвитку людини, формування ї̈ спів-буття. Ба більше, це метафізичні засаАи порядку всесвіту. Про що, власне, йАеться?

Згінно, наприклаА, з Гераклітом, «боги і мюди належать світлу» - це головне середовище їхнього спілкування. Світ народжується з темряви, з аб̆солютною ночі та оформлюється світлом, що безперервно повторюється у вигляді Аобових і сезонних циклів з їхнім ритмічним приростанням і спаданням світлового часу, а також у вигляді еонів, тобто великих хроноциклів, які переАбачають вічне повернення до первозАанного

\footnotetext{
2 У словнику В. Ааля світло - це «бочення, зір, світло очей, зАатність розрізняти очима, бачитиљ: Бог йому світла не Аав [Ааль, 1880-1882].

${ }^{3}$ Це ж значення простежується в похіАних мексемах: українське «освічений», польське «оร́wiecenie» «просвіта», словацьке та чеське «оsvěta» - «просвіта». Характерною рисою семантики похіАних ві৯ *svettсловоформ залишається зв'язок зі значенням позитивних характеристик, емоцій мюдини. АосліАники зазначають, що в історії слів спостерігається майже весь спектр цих характеристик: віА Аушевних якостей («бぇагий», «Аобрий») Ао характеристик зовнішності й Аобробуту («красивий», «багатий»).
} 
хаосу і світотворення «з нуля». Те ж формотворче сяйво космічно санкціонує і люАське відчуття зору [Соколов, 2011, с. 327]. А як зазначає Тіт Аукрецій Кар (сер. I ст. Ао н.е.), видимість матеріальних тіл не є нескінченною, іiі межею є «первинні тільця різної форми» (фАюїАи), що знаходяться в постійному русі [Аукрецій, 1988]. Цим пояснюються, наприклаА, запахи, випаровування вологи, формування зорових віАчуттів. У поемі «Про природу речей» визначальним у контексті нашої розвідки є те, що тут йлеться про формування зорового образу піА Аією навколишнього світу [Войцеховский, 2005; Аукрецій, 1988].

Зі свого боку Платон, розробляючи концепцію світла як неречовинної субстанції,

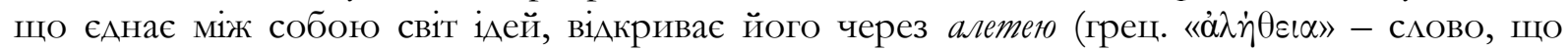
означає як «істину», так і «віАкритість», «звільнення з мороку», а пізніше, у гайдегтерівській інтерпретації - «непотаємність»). Так, розмірковуючи наА природою світла, Пцатон звертає свою увагу на те, що світло духовне, як і матеріальне, також є символом блага [Платон, 2000]. Чим світлішою і яскравішою є річ, тим більше вона є втіленою, осяжною та розумною. І взагалі - все існуюче є остільки, оскільки воно є світлим, оскільки воно є вияв еним i, отже, збагненним. Тож морок - як щось неосяжне - начебто й не існує. ОАнак Аля глибини пізнання одного тільки світла недостатньо: «сонце, як мені виАається, Аарує всьому, що ми бачимо, не мише можливість стати видимим, а й зародження, ріст і живлення, хоч саме воно зародженням не $є<$...> Визнай також і те, що пізнаваність предметів пізнання можлива лише завдяки добру і що воно є Ажерелом їхнього буття та існування, хоч саме добро насправді не є існуванням, воно понаА усяке існування - щось найлостойніше і найсильніше з усього» [Пцатон, 2000, с. 207]. Це, за Платоном, неявна Аля звичайного ока трансцендентна область існування блага, що є неосяжною, безмежною, істинно існуючою та проявленою кише керманичу Ауші - розуму. I саме на неї спрямовано «Ітииниий ріА знання» [ПАатон, 1965].

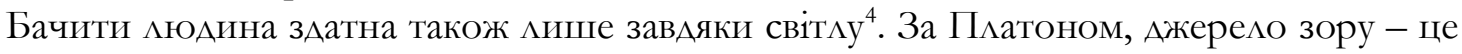
Ауша, яка за Аопомогою очей випромінюе конуси променів, що висвітАюють об’єкт. 3'єАнуючись із зовнішнім світлом, вони створюють особливе «зорове тіло», що тягнеться віА спостерігача до предмета [Стафеев \& Томилин, 2010]. Як зазначає філософ, з усіх органів боги насамперед влаштували світлоносні очі. За їхнім заАумом, повинно було виникнути тіло, яке не мало б пекучих властивостей звичайного вогню, але яке б вироблямо АагіАний вогонь, властивий Аню. I боги зробили так, що споріАнений Аенному світлу вогонь, який знаходиться всередині нас, випливає очищеним через очі, які затримують його «грубу» частину [Платон, 1986]. П^атон зазначає, що коли денне світло оточує потік зору, тоді подіб̈е входить до подіб̈нго, з'єАнується з ним і в напрямку зіниць утворює єАине «тіло», Ае те, що йде зсередини, не натрапляє на те, що зустрічає його 3зовні. А коли «споріАнений вогонь» уночі зникає, то й «вогонь очей» зникає теж, аАже останній, потрапляючи до «неподібного», і сам змінюється та гасне, тобто не з'єАнується 3 навколишнім повітрям, оскільки в ньому більше немає вогню (тут, отже, вогню Сонця віАповіАає магіАний вогонь очей, а заходу Сонця - змикання повік на ніч) [Платон, 1986].

${ }^{4} \mathrm{~V}$ філософії античності формується «теорія зорових променів», згіАно 3 якою бачення є результатом того, що самі очі, а не Сонце, випускають зорові промені, а потім ці промені поширюються по прямих Аініях у напрямку до об’екта і створюють враження видимості (Фалес, Піфагор, Геракліт, Емпедокл, Архіт, Платон, ЕвкліА, АрхімеА). Як доказ цієї теорії стародавні вчені наводили, скажімо, той факт, що очі деяких тварин світяться вночі. А очі сліпця, на їхню Аумку, не бачать з тієї причини, що не випускають променів. Емпедокл у своїх теоріях замість теорії зорових променів використовував ідею про «надтонкі щупальця», які виходять 3 очей спостерігача та «обіймають» певний об’єкт. Він вважав білий колір властивістю вогню, а чорний - властивістю води. Інша частина мислителів грецьких шкіл того періоду представ яяа зір у вигляді найтонших «фАюїдів», що випускаються віА об’єкта Ао ока (Аевкіпп і Аемокріт). Піфагор також вважав, що тіла стають видимими завдяки часткам, які вони випускають. ФАюїАами, що випускаються з очей спостерігача, а також минуть віА зовнішніх Ажерел, пізніше стали пояснювати зір Емпедокл і П^атон. Цю теорію піАтримували Сократ, Сенека, КАавАій Птолемей і КАавАій Гален. 
Тобто самі очі, щоб бачити, повинні бути в певному розумінні «світлими», «сонячними». Оскільки, як зазначає Пцатон [Пцатон, 1986], якби не було око сонячним, як би ми могли бачити світло? Якби не було в нас власної божественної сили, як би божественне захоплювало нас? Інакше кажучи, бачення очей «утворюється за допомогою світла А^я світла, щоб внутрішній світ виступив назустріч зовнішньому» [Гете, 2012].

Отже, розмірковуючи метафізичними категоріями, або інакше - розуміючи мюдину і навколишній світ як єдину, взаємопов’язану буттєвість, можна стверджувати наявність зв'язку між внутрішнім станом Аюдини (iі екзистенційною установкою) і навколишнім світом як живим, одухотвореним середовищем - $\chi \dot{\omega} \varrho \alpha^{5}$. Світло, що $\epsilon$ умовою порядку Всесвіту, самого життя, є тим, з чого починається саме буття, що сповнюе нас життєвою силою, що несумісне з будь-яким проявом темряви, невігластва, зла. А тому зАатні бачити навколишню реальність без спотворення (тобто об’єктивно, ціАісно) очі мише тієї Аюдини, яка впускає в себе це світло, стає його носієм, яка сприймає навколишній світ як життя, що потребує свого пізнання.

\section{СПИСОК ВИКОРИСТАНИХ АЖЕРЕ}

Белорусско-русский словарь / поА реА. К. К. Крапивы. М.: Гос. изА-во иностр. и нац. словарей, 1962. 1048 с.

Биболейская энциклопедия Брокгауза / сост. Ф. Ринекер, Г. Майер. М.: Российское Библейское Общество, 1999. 1120 c. URL: https://azbyka.ru/otechnik/Spravochniki/biblejska ja-entsiklopedija-brokgauza/1262.

Біб̆лія / пер. I. Огієнка. 2020. URL: https://bibleonline.ru/bible/ubio.

Большой матинско-русский словарь / по материалам словаря И. Х. Аворецкого. URL: http://linguaeterna.com/vocabula/.

Войцеховский А. И. Загадки Аревних святынь. М.: Вече, 2005. 384 с.

Гете И. В. фон. Учение о цвете. Теория познания: сборник работ / пер. с нем. М.: Аиброком, 2012. 200 c. URL: https://www.rulit.me/books/uchenie-o-cvete-teoriya-poznaniyadownload-424361.html.

\footnotetext{
5 Поняття $\chi \dot{\omega} \varrho \alpha$ вводитися Платоном у Аіалозі «Тімей», який, на Аумку Аж. Салліса, можна розглядати власне як хоро-логію [Sallis, 1999, p. 9]. На Аумку Пцатона, Аля того, щоб мати змогу говорити про початок Всесвіту, і «преАставити його народження так, як воно Аійсно віАбувалося» [ПАатон, 1994, с. 450], необхіАно, крім аналізу його буття й становлення, «розглянути, якою була сама природа вогню, води, повітря й землі до народження неба, і яким був їхній тодішній стан» [ПАатон, 1994, с. 451]. Філософ доходить висновку, що жодна зі стихій не є першоосновою, оскільки не володіє «самістю», а є лише формою прояву якогось глибинного змісту [Цатон, 1994, с. 95]. Вказуючи на неможливість іменування стихій, Пцатон стверджує, що «тільки сутність, всередині якої вони [стихіi] отримують народження і до якої повертаються, гинучи, ми назвемо “те” і “це”» [Пкатон, 1994, с. 452]. Отже, третій ріА є немовбии «хрещеною матір”ю та

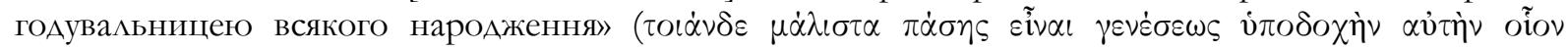

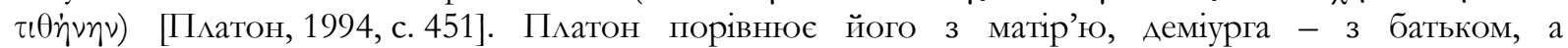
породжуваний світ речей - 3 Аитиною.

Аля позначення третього роду Платон використовує слово $\chi \dot{\omega} \varrho \alpha$, яким найчастіше позначається «земля» (у значенні країни), а також територія, що знаходиться за межами поліса, але піАлягає його юрисдикції (буквально - «навколишні землі»). Як філософське поняття хора набуває значення (і віАповіАно переклаАається) і як простір, i як матерія, i як «хрещена матір», вмістилище [Sallis, 1999, pp. 12, 98-99]. Хора є водночас і невидимою, і не-невидимою. Вона є недоступною Аля чуттєвого сприйняття, оскільки «як третій рід “сприймається поза відчуттями, за

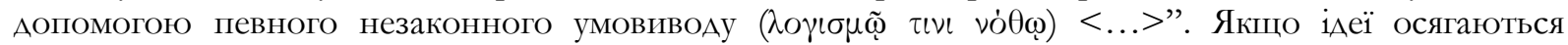
розумом, а речі - шляхом “істинної Аумки", що передбачає тілесні відчуття, то хора не може бути виявлена ані в розумі, ані в чуттєвому сприйнятті. Образ хори (але не сама вона) являється нам лише "у мріях" або "сонному забутті", оскільки тільки порівнявши Аійсність зі сном, ми можемо прийти Ао усвіАомлення того, що "образ не в собі самому має причину свого народження, але незмінно явАяє собою привиА чогось іншого", і він тому “і мас народитися всередині чогось іншого, немов приліпившись до суті, або взагалі не бути нічим”» [Петров, 2015, с. 54-81].
} 


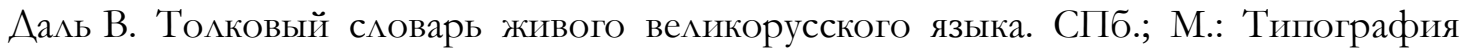
M. Вольфа, 1880-1882. URL: http://slovardalja.net.

Аревнегреческо-русский словарь: в 2-х т.; т. 2 / сост. И. Х. Аворецкий. М.: Гос. изАво иностр. и нац. словарей, 1958. URL: http://graecolatini.bsu.by/dictionaries-oldgreek.htm.

Еврейская энциклопедия Брокгауза и Ефрона: в 16-ти т. / под реА. А. Гаркави, А. Гинцбург, Ю. Гессен, С. Аубнов, И. Маркон, Н. Переферкович. СПб.: Брокгауз-Ефрон, 1906-1913. URL: https://www.runivers.ru/lib/book7069/.

Аукрецій Кар Тіт. Про природу речей: поема / пер. $з$ мат. А. Содомора. К.: Аніпро, 1988. 191 c.

Петров В. Негативный аспект определения социального пространства: понятие $\chi \omega ́ \varrho \alpha$ у П^атона и в современности. Философскал мыссль. 2015. № 8. С. 54-81. DOI: https://doi.org/10.7256/2409-8728.2015.8.16195.

П^атон. Аержава / пер. 3 Аавньогр. А. Коваль. Київ: Основи, 2000. 355 с. 1986. $607 \mathrm{c}$.

Платон. Аиалоги / пер. с Аревнегреч. С. Я. Шейнман-Топштейн. М.: Мысль,

П^атон. Тимей / пер. с Аревнегреч. С. С. Аверинцев, А. Н. Егунов, Н. В. Самсонов. Собрание сочинений: в 4-х т.; m. 3. М.: Мысль, 1994. С. 421-500.

Платон. Федр (отрывок) / пер. с Аревнегреч. С.А. Жебелев; под. реА. Н. Ф. Аератани, Н. А. Тимофеева. Хрестоматия по античной литературе: в $2-x$ m.; m. 1 . М.: Просвещение, 1965. С. 468-473.

Полный церковнославянский словарь Аьяченко (1899). 2020. URL: https://azbyka.ru/otechnik/Grigorij_Djachenko/polnyj-tserkovnoslavjanskij-slovar.html.

Словарь русского языка XI-XVII вв. / под ред. Г. А. Богатовой. М.: Наука, 1996. Вып. 23. 253 с.

Словарь русского языка: в 4-х т.; т. 2 / под ред. А. П. Евгеньевой. М.: Русский язык, 1983. 736 c. URL: https://azbyka.ru/otechnik/books/original/25053/MAC\%20т2.pdf.

Соколов М. Принцип рая: ГАавы об иконологии сада, парка и прекрасного виАа. М.: Прогресс-Традиция, 2011. 704 с.

Срезневский И. Словарь Аревнерусского языка: в 3-х т.; т. 3, ч. 1 / репринт. изА. 1893 г. М.: Книга, 1989. 910 с. URL: http://oldrusdict.ru/dict.html.

Стафеев С., Томилин М. Пять тысячелетий оптики: Античность. СПб: Форма Т, 2010. 526 c.

Франк С. Свет во тьме. М.: Факториал, 1998. 256 с. 1997. 452 c.

Хайдеггер М. Бытие и время / пер. с нем. В. В. Бибихина. М.: Ad Marginem,

Штейнзальц А. Свет в философии хасидизма. Иерусалим: Институт изучения иудаизма в СНГ, 1998. URL: https://www.berkovich-zametki.com/Nomer22/Steinsalz1.htm.

Этимологический словарь славянских языков / под ред. О. Н. Трубачёва. М.: Наука, 1975. Вып. 2. 238 с.

Miklošich F. Etymologisches Wörterbuch der slavischen Sprachen. Wien: W. Braumüller, 1886. $548 \mathrm{~s}$.

Sallis J. Chorology: On Beginning in Plato's Timaeus. Indianapolis: Indiana University Press, 1999. 172 p.

\section{Бродецька Юлія Юріївна}

Аокторка філософських наук, доцентка кафелри філософії

Аніпровський національний університет імені ОАеся Гончара

пр. Гагаріна, 72, Аніпро, 49010

E-mail: yuliaybrod@gmail.com

ORCID: http://orcid.org/0000-0001-9186-0767

Стаття надійшла до редакції: 13.10.2020

Схвалено Ао Аруку: 24.11.2020 


\title{
THE METAPHYSICAL NATURE OF KNOWLEDGE: ENLIGHTENING LIGHT
}

\author{
Brodetska Yuliia Yu. \\ DSc in Philosophy, Associate Professor of the Department of Philosophy \\ Oles Honchar Dnipro National University \\ 72, Gagarin Avenue, 49010, Dnipro, Ukraine \\ E-mail: yuliaybrod@gmail.com \\ ORCID: http://orcid.org/0000-0001-9186-0767
}

\begin{abstract}
The article is devoted to the analysis of the knowledge phenomenon as a metaphysical basis for the being order. It is the semantic content of this word that retains the meaning of "the light of truth", "reason", "word". This allows a human to see the world around him, that is, makes the world "manifested, clear, understandable". We are talking about knowledge that reflects a purely spiritual nature, which means that this knowledge is directed to the very essence of the human soul. This is, in its essence, valuable knowledge that "heals", that is, unites, makes all aspects of human nature (spiritual, physical) one whole. Therefore, this knowledge requires a special perception from a person, makes us feel, go deeper into what we know. As an "ether", that is, an information environment that is able to fill, inspire a person, transform, connect, reproduce his connections with reality, spiritual knowledge leads to the correspondence of the individual to the ontological laws of joint existence. In other words, these are the principles that underlie the integrity of human existence - its development, the formation of the space of co-existence. That is, we are talking about the metaphysical foundations of the order of the universe. In this perspective, we are talking about the fact that the basis of human existence, its correspondence and correlation, is the need for spiritual knowledge. It is the latter that are that transcendental light, which is endowed with transformative potency. Knowing what corresponds to the nature of a person's sensibility, the needs of his soul. So, the need to discover this knowledge for oneself is cognition, and is the potential force that moves a person in her life choices, builds the meaning and perspective of her life. If we understand human and the world around him as a coexistence, then we are talking about the relationship between the inner state of the individual (his existential attitude) and the world around him, which is a living, dynamic environment. Light is an ontological order et life condition. In its metaphysical status, light is the basis of being itself, and, therefore, that which fills us with life force, which is incompatible with any manifestation of darkness, ignorance, evil. That is why the ability to see the surrounding reality without distortion, that is, objectively, holistically, is revealed only to the person who is the bearer of this light.
\end{abstract}

Keywords: knowledge, cognition, metaphysics, light, co-existence.

\section{REFERENCES}

Bible. (2020). (I. Ogienko, Trans.). Retrieved from https://bibleonline.ru/bible/ubio. (Original translation published 1962). (In Ukrainian).

Bogatova, G. A. (Ed.). (1996). Dictionary of the Russian Language XI-XVII Centuries (Issue 23). Moscow: Nauka. (In Russian).

Dal, V. (1880-1882). Explanatory Dictionary of the Living Great Russian Language. Saint Petersburg; Moscow: M. O. Volf Publisher. Retrieved from http://slovardalja.net. (In Russian).

Dvoretsky, I. Kh. (Ed.). (1958). Ancient Greek-Russian Dictionary: In 2 Vols (Vol. 2). Moscow: State Publishing House of Foreign and National Dictionaries. Retrieved from http://graecolatini.bsu.by/dictionaries-oldgreek.htm. (In Russian).

Dyachenko's Complete Church Slavonic Dictionary. (2020). Retrieved from https://azbyka.ru/otechnik/Grigorij_Djachenko/polnyj-tserkovnoslavjanskijslovar.html. (Original work published 1899). (In Russian).

Evgenieva, A. P. (Ed.). (1983). Dictionary of the Russian Language: In 4 Vols. (Vol. 2). Retrieved from https://azbyka.ru/otechnik/books/original/25053/MAC\%20т2.pdf. Moscow: Russian Language. (In Russian).

Frank, S. (1998). Light in the Dark. Moscow: Factorial. (In Russian). 
Goethe, J. W. von. (2012). Theory of Colours. Theory of Knowledge: The Collected Writings. Moscow: Librokom. Retrieved from https://www.rulit.me/books/uchenie-o-cvete-teoriyapoznaniya-download-424361.html. (In Russian).

Great Latin-Russian Dictionary Based on Dvoretsky's Dictionary Materials. (2020). Retrieved from http://linguaeterna.com/vocabula/. (In Russian).

Heidegger, M. (1997). Being and Time. (V. V. Bibikhin, Trans.). (Original work published 1927). Moscow: Ad Marginem. (In Russian).

Jewish Encyclopedia of Brockhaus and Efron: In 16 Vols. (1906-1913). Saint Petersburg: Brockhaus-Efron Publishing House. Retrieved from https://www.runivers.ru/lib/book7069/. (In Russian).

Krapiva, K. K. (Ed.). (1962). Belarusian-Russian Dictionary. Moscow: State Publishing House of Foreign and National Dictionaries. (In Russian).

Lucretius Carus Titus. (1988). On the Nature of Things. (A. Sodomora, Trans.). Kyiv: Dnipro. (In Ukrainian).

Miklošich, F. (1886). Etymologisches Wörterbuch der Slavischen Sprachen. Wien: W. Braumüller. (In German).

Petrov, V. (2015). The Negative Aspect of the Definition of Social Space: A Concept of $\chi \omega \dot{\omega} \propto \alpha$ in Plato and in Modern Times. Fylosofskaia Mysl-Philosophical Thought, 8, 54-81. (In Russian). DOI: https://doi.org/10.7256/2409-8728.2015.8.16195.

Plato. (1965). Phaedrus (Fragment). (S. A. Zhebelev, Trans.). In N. F. Deratani \& N. A. Timofeeva (Eds.), Anthology of Ancient Literature: In 2 Vols. (Vol. 1, pp. 468-473). Moscow: Prosvieshchienie. (In Russian).

Plato. (1986). Dialogues. (S. Ya. Sheinman-Topstein, Trans.). Moscow: Mysl. (In Russian).

Plato. (1994). Timaeus. (S. S. Averintsev, A. N. Egunov \& N. V. Samsonov, Trans.). In Plato, The Collected Writings: In 4 Vols. (Vol. 3, pp. 421-500). Moscow: Mysl. (In Russian).

Plato. (2000). Republic (Moגızia). (D. Koval, Trans.). Kyiv: Osnovy. (In Ukrainian).

Rinecker, F., \& Mayer, G. (Eds.). (1999). Bible Encyclopedia of Brockhaus. Moscow: Russian Bible Society. Retrieved from https://azbyka.ru/otechnik/Spravochniki/biblejskajaentsiklopedija-brokgauza/1262. (Original work published 1960). (in Russian).

Sallis, J. (1999). Chorology: On Beginning in Plato's Timaeus. Indianapolis: Indiana University Press.

Sokolov, M. (2011). The Principle of Paradise: Chapters on the Iconology of the Garden, Park and Beautiful View. Moscow: Progress-Tradition. (In Russian).

Sreznevsky, I. (1989). Dictionary of the Old Russian Language: In 3 Vols. (Vol. 3, Part 1). Moscow: Kniga. Retrieved from http://oldrusdict.ru/dict.html. (Original work published 1893). (In Russian).

Stafeev, S., \& Tomilin, M. (2010). Five Millenniums of Optics: Antiquity. Saint Petersburg: Publishing House "Forma T". (In Russian).

Steinsaltz, A. (1998). Light in the Philosophy of Hasidism. Jerusalem: Institute for the Study of Judaism in the CIS. Retrieved from https://www.berkovichzametki.com/Nomer22/Steinsalz1.htm. (In Russian).

Trubachev, O. N. (Ed). (1975). Etymological Dictionary of Slavic Languages (Issue 2). Moscow: Nauka. (In Russian).

Voitsekhovsky, A. (2005). Riddles of Ancient Shrines. Moscow: Veche. (In Russian).

Article arrived: 13.10 .2020

Accepted: 24.11.2020 